\title{
CANCER OF THE LUNG IN PROGRESSIVE SYSTEMIC SCLEROSIS
}

\author{
BY \\ R. L. RICHARDS AND J. A. MILNE \\ From the Departments of Medicine and Pathology, the University and Western Infirmary, Glasgow
}

(RECEIVED FOR PUBLICATION JANUARY 22, 1958)

An association between one of the collagen diseases, dermatomyositis, and malignant disease is well recognized; in a recent review Caldwell (1955) states that there are nearly 70 reported cases in which the association has been noted, and an incidence of $18 \%$ malignancy in cases of dermatomyositis has been reported by Curtis, Blaylock, and Harrell (1952). Many authorities (Dowling, 1940 ; Freudenthal, 1940 ; Goetz, 1945 ; Pagel and Treip, 1955) think that dermatomyositis and the condition which is commonly called generalized or diffuse scleroderma, but which we along with others (Goetz, 1945 ; Cullinan, 1953 ; Beigelman, Goldner, and Bayles, 1953 ; Piper and Helwig, 1955), believe is better called progressive systemic sclerosis, are variants of the same disease. It is therefore of interest that a similar association between malignant disease and progressive systemic sclerosis is apparently rare (Talbott and Ferrandis, 1956). Apart from a report by Barlow (1939) of a patient who had diffuse scleroderma and who was found at necropsy to have an apparently simple adrenal adenoma, there were no definite records of neoplasia in cases of progressive systemic sclerosis until 1953 when Zatuchni, Campbell, and Zarafonetis reported three patients who had scleroderma, pulmonary fibrosis, and carcinoma of the lung. Jonsson and Houser (1956) have since reported another similar case. In the last two years we have seen two patients who had this combination of progressive systemic sclerosis and pulmonary carcinoma. The purpose of this paper is to present these two cases in detail, to review briefly the findings in the cases previously reported, and to discuss the association between the two diseases.

\section{CASE Reports}

CASE 1.-A 50-year-old housewife was first seen in July, 1953. She had suffered from attacks of the Raynaud phenomenon in both hands for about 18 years. For two or three years she had noticed that her hands were becoming stiff and she had been troubled with whitlows at the tips of the fingers. She was also aware that her mouth was becoming smaller and as a result she was having difficulty with her dentures. For some months she had experienced intermittent dysphagia. Three months previously she had a respiratory illness associated with pain in the left chest, fever, cough, and sputum. This was diagnosed as pneumonia and treated as such by her own doctor. Since this illness she had been breathless on exertion and she complained of a feeling of tightness across the upper chest, not definitely related to exertion. There was no history of any previous respiratory trouble and her past and family histories were otherwise negative. She did not smoke.

On examination the facial appearance and the hands were typical of acrosclerosis (Figs. 1 and 2). The feet were also affected. The cardiovascular system was normal apart from the presence of a short systolic murmur at the cardiac apex; blood pressure was $125 / 80 \mathrm{~mm}$. of mercury. Chest expansion was poor and any attempt at deep inspiration would provoke a bout of coughing. The percussion note was normal on both sides, but on auscultation there were numerous coarse rales throughout both lung fields, more marked on the right. The abdomen and the central nervous system were normal and there was no abnormality in the urine.

In the blood, the haemoglobin concentration was $90 \%$, leucocytes 6,700 per c.mm., and erythrocyte

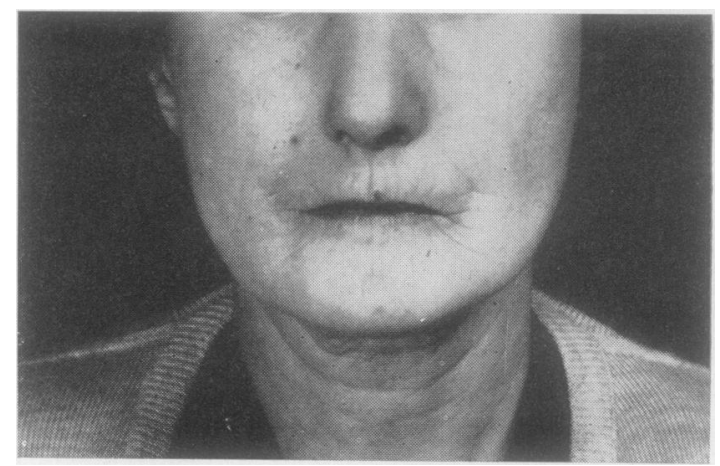

FIG. 1.-Case 1: Appearance of face, typical of acrosclerosis. 


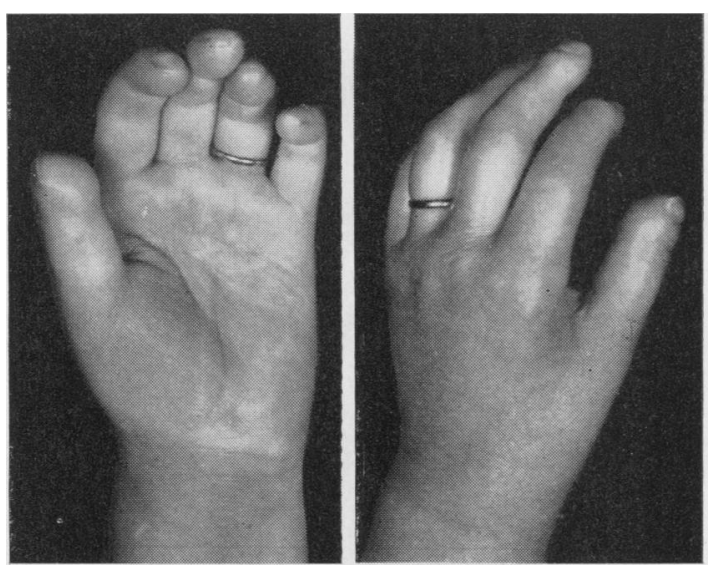

Fig. 2.-Case 1: Palmar and dorsal views of left hand.

sedimentation rate $38 \mathrm{~mm}$. in the first hour (Westergren). The Wassermann reaction was negative. Radiography of the chest showed a normal cardiac shadow, some mottling in the right infraclavicular region and extensive mottling at both lung bases (Fig. 3) ; the hands showed absorption of the terminal phalanges typical of acrosclerosis, and a barium swallow demonstrated a slight delay in the passage of barium through the lower end of the oesophagus, but no organic stricture. Sputum was scanty, but bacteriological examination of a specimen gave a rich mixed growth including a few colonies of $\beta$-haemolytic streptococci and pneumococci; examination and culture for tubercle bacilli were negative. The electrocardiogram showed rather low voltage $T$ waves but was otherwise normal. A biopsy of skin from the right ankle showed the histological appearances of acrosclerosis; a portion of muscle from the tibialis anterior was normal.

She was treated with cortisone, $200 \mathrm{mg}$. on the first day, $100 \mathrm{mg}$. daily for four days, and then $50 \mathrm{mg}$. daily. There was some improvement in the mobility of the hands, but the respiratory symptoms and signs remained unchanged. After six weeks cortisone was stopped, but the subjective improvement in the hands was maintained.

In November, 1953, she was readmitted to hospital with an acute respiratory infection. She had pyrexia with rigors, cough with apricot-coloured sputum, and pain in the left chest. On examination she was very ill and there were signs of consolidation at both lung bases. In spite of this the radiological appearances in the chest showed little change. She responded well to treatment with penicillin. During this illness the condition of the hands deteriorated and, because of this, steroid therapy was restarted and cortisone, $50 \mathrm{mg}$. daily, was given for about two months.

For about 15 months after this episode she was reasonably well and able to be up and about although very breathless and troubled by an unproductive cough, especially at night and always worse when she lay on her right side. The signs in the chest remained about the same and the radiographic appearances altered only slightly (Fig. 4). It was at this time that attention was first focused on a denser area in the hilar region towards the right base which, in retrospect, was also present in the earlier films.

In March, 1955, she was again in hospital with an attack of profound weakness and respiratory infection. On this occasion she had a small haemoptysis, and was found to have a normochromic, normocytic anaemia with a haemoglobin of $70 \%$. Treatment with penicillin was again effective.

During the summer of 1955 she was able to be up and about, but from October onwards she became more breathless and was confined to bed. In January, 1956, she was readmitted with orthopnoea, cyanosis, and slight oedema of the ankles and sacral region. The signs in the chest and the radiograph suggested that she had a large right pleural effusion, but repeated attempts to aspirate fluid were unsuccessful. She required almost continuous oxygen therapy. At first there was some slight improvement, but thereafter her condition slowly deteriorated and she died on March 17, 1956.

Necropsy.-The body was that of a thin, elderly, wasted female. The changes of advanced scleroderma affecting the skin of the face, neck, hands, and feet were present. Apart from this the main pathological

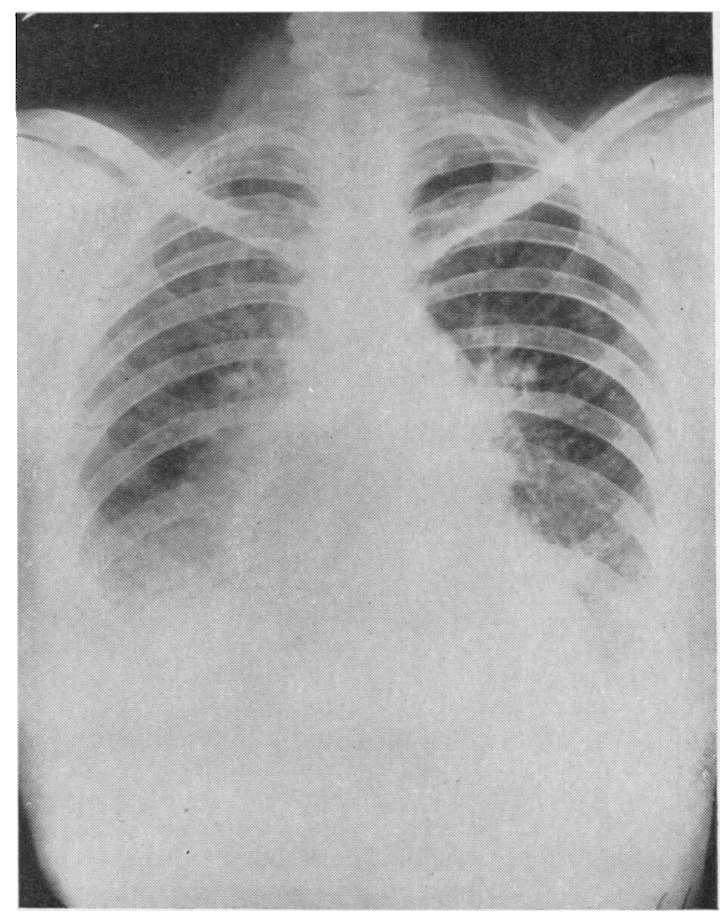

Fig. 3.-Case 1: Chest radiograph, July, 1953; note diffuse mottling throughout both lung fields especially at bases and in left infraclavicular region. 


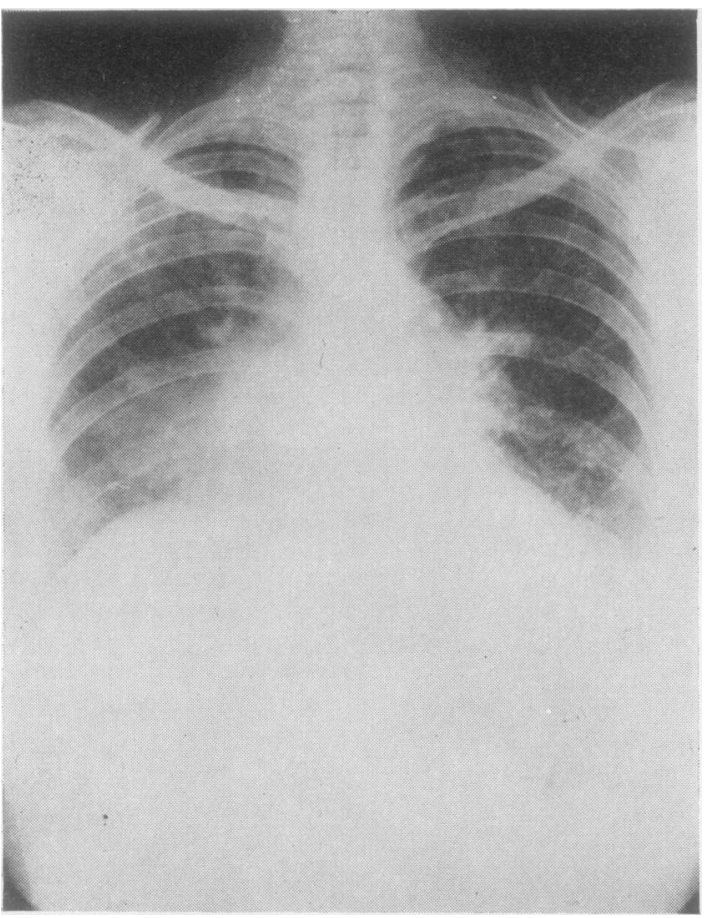

FIG. 4.-Case 1: Chest radiograph, Docember, 1954 ; note opacity in the right hilar zone.

changes were found in the thorax and only these will be described in detail. There were dense fibrous adhesions over the apex of the left lung and the lower lobe was covered with a fibrinous exudate. The right pleural space was completely obliterated; the visceral and parietal layers of pleura were replaced by a thick sheet of fibrous tissue $1 \mathrm{~cm}$. thick which completely invested the lung and was firmly adherent to the wall of the thorax. In some places the thickened pleural layers had remained separate and formed the walls of rigid cysts which contained a mixture of blood clot, fibrin, and serum. The largest of these cysts at the apex of the lung measured 6 to $8 \mathrm{~cm}$. diameter. The larynx, trachea, and main bronchi were of normal appearance, but on section of the right lung a carcinoma apparently arising from the main lower lobe bronchus and completely occluding it was found. The whole of the right middle and lower lobes appeared to be extensively infiltrated with tumour tissue and there was also some infiltration of the peripheral portions of the upper lobe although the central and para-hilar parts of this lobe appeared normal. On the left, the upper lobe was macroscopically normal, but the lower lobe showed widespread cystic changes, the cysts being small, $5 \mathrm{~mm}$. or less in diameter. This lobe was greyish due to pneumonic consolidation. The right hilar and tracheo-bronchial lymph nodes were infiltrated with cancer, but were not greatly enlarged. The left hilar nodes were free from tumour. The pericardial sac contained about $100 \mathrm{ml}$. of blood-stained fluid and the parietal pericardium on the right was thickened, hard, and clearly infiltrated by cancerous tissue. The visceral pericardium was normal. The heart appeared normal. Tumour had spread through the right lobe of the diaphragm. Metastatic tumour deposits were found in the liver, stomach, adrenals, spleen, and pancreas.

Histology.-The tumour in the right lung was found to be a moderately well differentiated adenocarcinoma (Fig. 5). Sections of those portions of the lungs which were not affected by tumour showed a great increase in the thickness of the fibrous septa between the alveoli and of the peribronchial connective tissue (Fig. 6). The cysts in the left lower lobe were of three types: (1) Dilated bronchi lined by typical bronchial epithelium, (2) cystic spaces lined by a single layer of flattened epithelium, and (3) spaces with fairly dense collagenous walls, but without recognizable lining epithelium (Fig. 7). In the collagenous tissue between the cysts there was considerable lymphocytic and plasma cell infiltration. No significant lesions were found in the blood vessels of the lungs.

CASE 2.-A 65-year-old undertaker was seen as an out-patient in January, 1956. He complained that for three months he had been troubled by painful sores

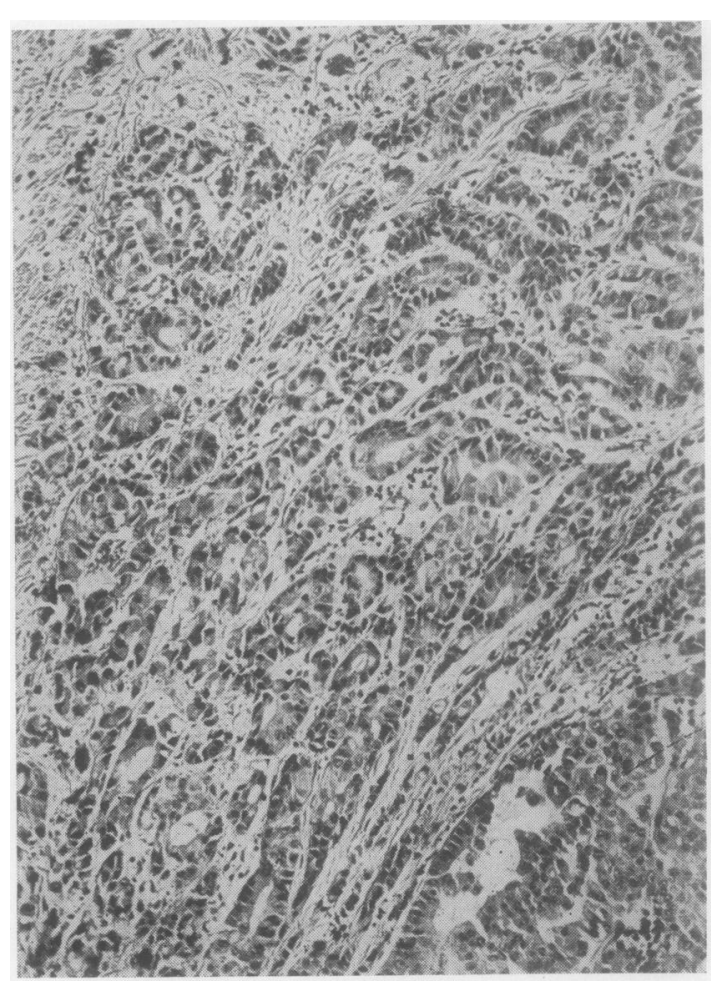

Fig. 5.-Case 1: Histology of tumour (haematoxylin and eosin $\times 120)$; moderately well differentiated adenocarcinoma of lung. 


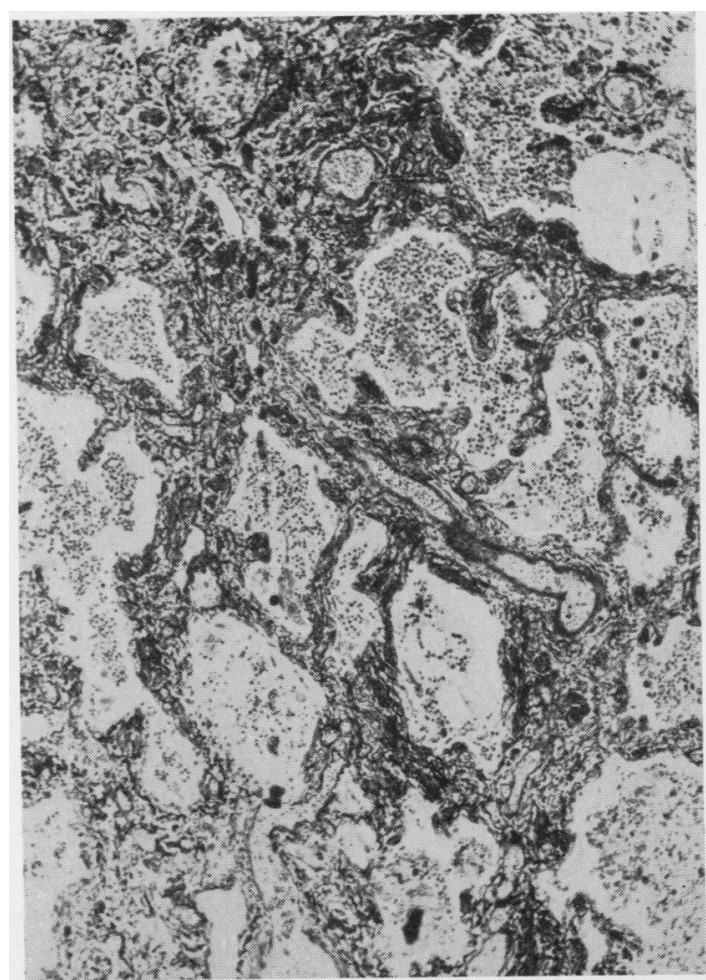

FIG. 6.-Case 1: Histology of lung unaffected by tumour (Masson $\times 210)$; increased fibrosis between alveoli.

on the tips of his fingers. His hands always felt cold and frequently the tips of all the fingers of both hands would become white, blue, or even black, as far as the first joint. His general health was good, and although he was a little short of breath on exertion he had no other respiratory symptoms. He had smoked approximately 15 cigarettes per day for many years.

On examination he appeared to be his stated age. The brachial arteries were palpably thickened and tortuous and the blood pressure was $175 / 100 \mathrm{~mm}$. of mercury. The heart was not clinically enlarged and the sounds were normal. In the chest there were a few scattered rhonchi only. At this time his facial appearance was not considered abnormal. The hands were reddish and cold, there were small scars on the tips of the second, third, and fourth digits of both hands, but apart from this the skin of the hands was thought to be normal. The radial and ulnar pulses were easily felt at both wrists.

The radiograph of the chest showed normal lung fields, and those of the hands only a small area of calcinosis in the left middle finger.

The patient was not seen again for some months, but in September, 1956, he was admitted to hospital because the condition of his hands was getting worse. It was now apparent that the skin of both the face and the hands was involved and a clinical diagnosis of acrosclerosis was made and confirmed by skin biopsy. Apart from some exertional dyspnoea he still had no respiratory symptoms and no dysphagia or other complaints referable to the alimentary system. Clinically there were only a few scattered rhonchi in the chest, but radiologically there was now a small left pleural effusion. A barium swallow was given. This did not show the delay at the lower end of the oesophagus which is the usual finding in systemic sclerosis, but it was noted that there was a constant smooth zone of narrowing in mid-oesophagus.

He was treated with prednisolone, $20 \mathrm{mg}$. three times a day, and physiotherapy for his hands. This had little, if any, effect. He became more breathless and developed an irritating dry cough which prevented him from sleeping. By the end of November he could walk only a short distance before he had to stop because of breathlessness. There were now signs of a large left pleural effusion and a small hard lymph node was palpable in the left supraclavicular fossa. Radiography of the chest confirmed the presence of the left pleural effusion and suggested that there was also some pulmonary collapse: the superior mediastinal shadow was enlarged. Two and a half pints of blood-stained fluid were aspirated from the left chest. Malignant cells were not found in this

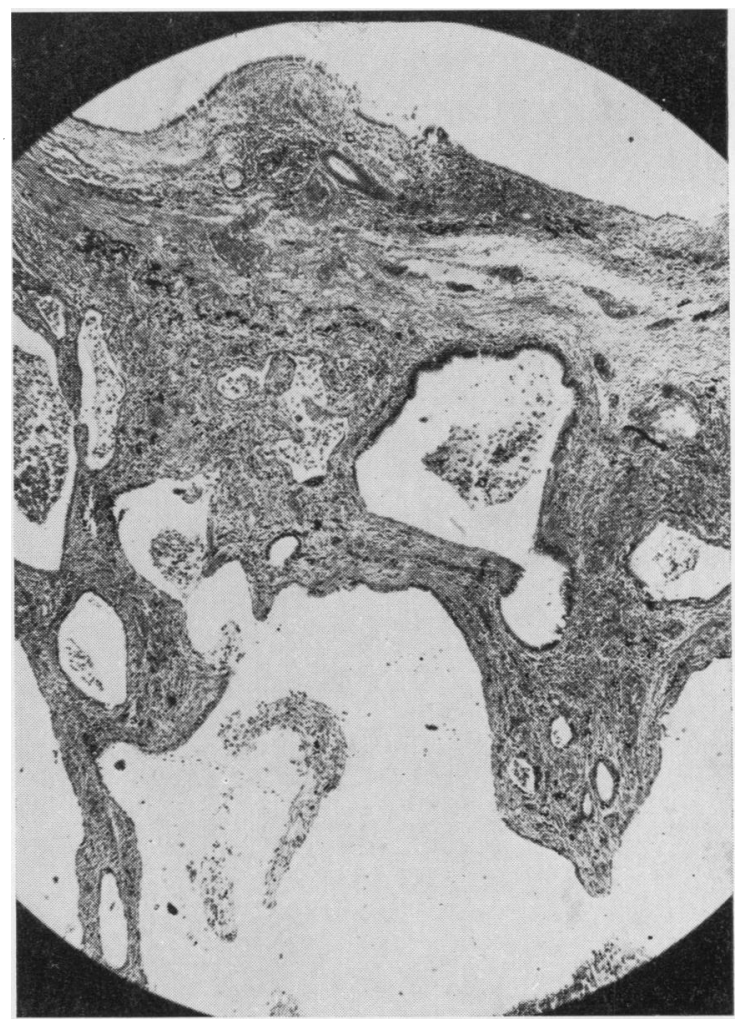

FIG. 7.-Case 1: Cystic area of lung (haematoxylin and $\operatorname{cosin} \times 30$ ); some of the cysts are lined with epithelium and some are not. 
fluid. His condition rapidly deteriorated and he died on December 17, 1956.

Necropsy Findings.-Necropsy was performed a few hours after death. Apart from the changes of acrosclerosis in the hands and feet which had been noted during life, the abnormal findings were confined to the chest and these only will be described. The left pleural cavity contained 2 litres and the right $1 \frac{1}{2}$ litres of clear, straw-coloured fluid. The lungs were collapsed. The anterior mediastinum was occupied by a mass of soft, pinkish-white tumour tissue with areas of haemorrhage and necrosis. The trachea was normal, but close to its origin the right main bronchus showed submucosal infiltration by malignant tissue. This tumour encircled the main bronchi of the right lung and extended into the mediastinum and on to the parietal pericardium. The tumour had also extended backwards and encircled and compressed the oesophagus. Otherwise the lungs showed only a moderate degree of vesicular emphysema. There were no distant tumour metastases.

Histology. - The tumour was an anaplastic spheroidal cell carcinoma of predominantly small cell type (Fig. 8). The remainder of the lungs showed some emphysema, most marked in the subpleural regions. There was a slight increase in the fibrous tissue of the septa, but as there was anthracosis of the

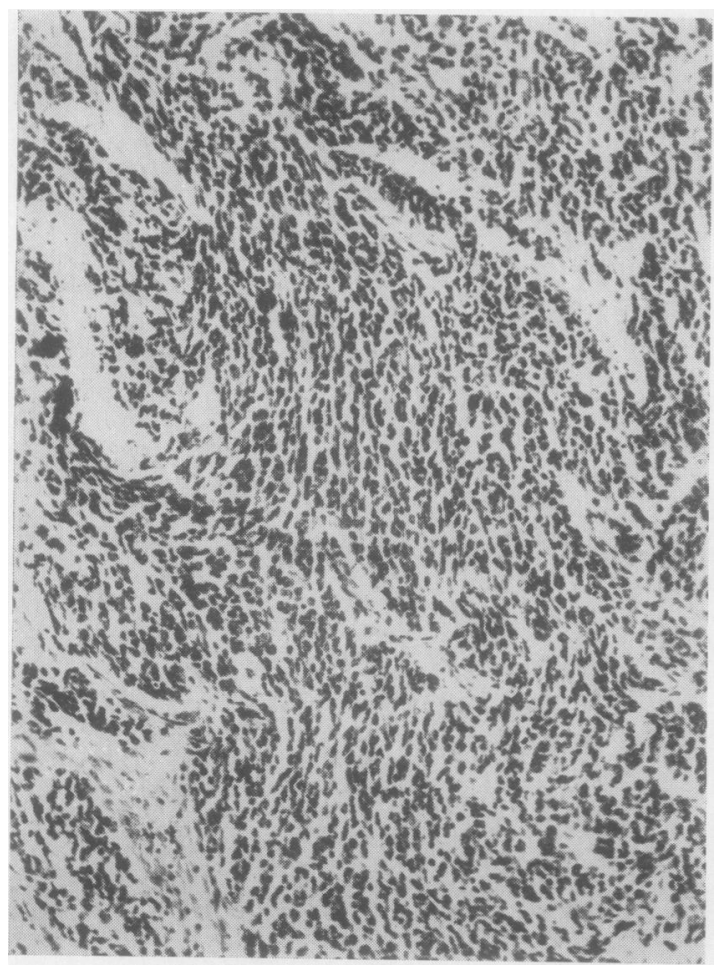

FIG. 8.-Case 2: Histology of tumour (haematoxylin and eosin $\times 120)$; anaplastic small cell carcinoma.

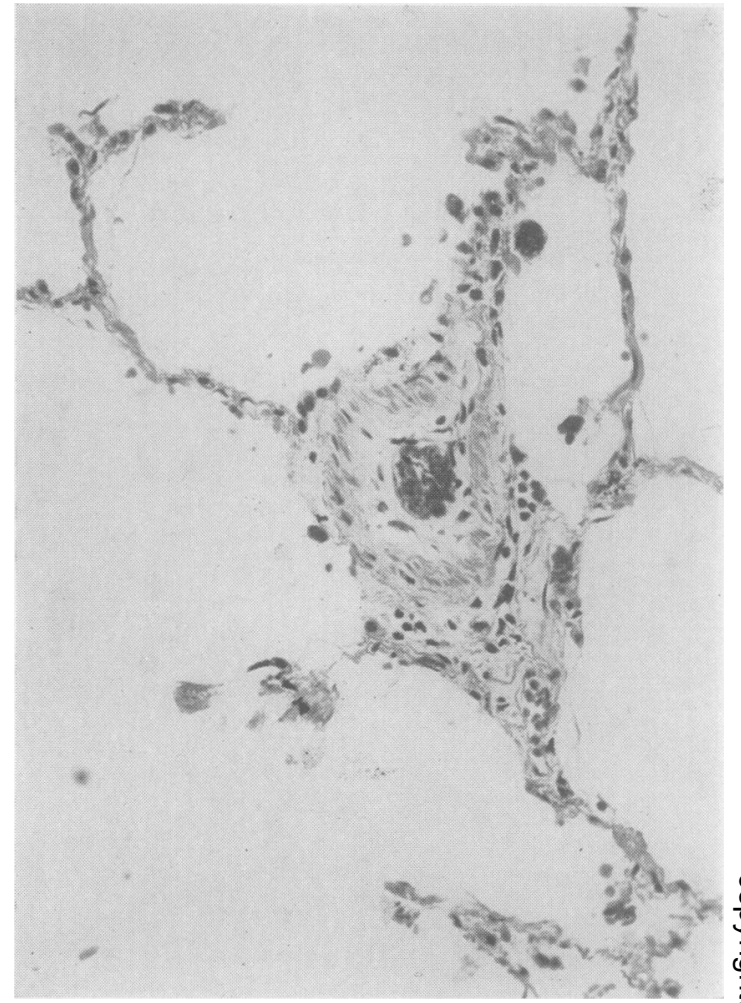

FIG. 9.-Case 2: Histology of lung (haematoxylin and eosin $\times 210$ ); small pulmonary arteriole showing oedematous thickening of intima similar to that seen in interlobular arteries in "scleroderma" kidney.

lung these changes were probably not significant. The smaller branches of the pulmonary artery showed diminution of their lumina by cellular oedematous intimal thickening similar to the appearances seen in the intralobular arteries in the so-called " scleroderma kidney" (Fig. 9).

\section{Discussion}

The name progressive systemic sclerosis is preferred to diffuse scleroderma because it emphasizes the fact that the disease is not confined to the skin but is a generalized process with visceral as well as cutaneous manifestations. The lungs are among the viscera which are frequently affected; Piper and Helwig (1955) found pulmonary lesions in $90 \%$ of 31 fatal cases, and in a personal series of 18 cases 11 have some pulmonary manifestations. Good descriptions of the pulmonary changes from the clinical, pathological, and radiological aspects are to be found in the papers of Getzowa (1945), Lloyd and Tonkin (1948), Spain and Thomas (1950), Hayman and Hunt (1952), and Shuford, Seaman, and Goldman 
(1953). The pulmonary manifestations usually accompany or follow the cutaneous changes; rarely they may precede the latter. The lesion in the lungs is a form of pulmonary fibrosis which is sometimes accompanied by cystic changes. Clinically the patients complain of increasing dyspnoea which in a few cases may be due partly to the rigidity of the chest wall from skin involvement but is most often the result of the rigidity of the lung tissue itself (Church and Ellis, 1950). Cough is common but sputum is usually scanty except in attacks of acute respiratory infection which, as in Case 2, may occur frequently. Haemoptysis is rare. Recently Israel and Harley (1956) have recorded a case in which spontaneous pneumothorax occurred. The radiological changes are of two types; the more common is a diffuse linear type of infiltration most marked in the lower half of the lung fields. This change may be noted in patients who have no respiratory symptoms. Cystic changes are less commonly seen radiologically. Histologically the picture is that of an increase in the connective tissue of the lungs, the alveolar septa being replaced by an acellular type of fibrous tissue. In cases with cyst formation the cysts, which form mainly in the subpleural zone, may be lined with epithelium of various types, columnar, cuboidal, or flattened, but frequently they have walls of fibrous tissue only (Case 1). The capillaries in the septa between the alveoli tend to be obliterated and the main arteries and arterioles frequently show intimal thickening.
Details of the six cases in which cancer of the lung has been found in association with progressive systemic sclerosis are presented in Table $\mathbf{I}$. Five of these (Cases 1 and 3-6) appear to be similar to one another; all were females and all were known to have systemic sclerosis for many years before they died of carcinoma. In at least four of them pulmonary manifestations had been present for a considerable time. It can therefore be postulated that in these patients the lesions of the primary disease in the lungs were a premalignant condition in which neoplastic changes eventually developed. In support of this hypothesis it is to be noted that Getzowa (1945) in her two cases of systemic sclerosis with pulmonary manifestations found areas in the cystic portions of the lungs which she described as pseudoadenomatous and in which extensive bronchiolar proliferation was observed. Mahrer, Evans, and Steinberg (1954) also noted bronchiolar hyperplasia in two of their cases which showed cystic changes. Of the five cases with cancer of the lung, all showed the diffuse interstitial changes of progressive systemic sclerosis in the parts of the lungs unaffected by tumour, but cystic changes were present in only two (Cases 1 and 6). The hypothesis that the pulmonary lesions of progressive systemic sclerosis may be a pre-malignant condition is considered by Zatuchni and others (1953) and by Jonsson and Houser (1956). The former consider that it can only be speculative to suggest a causal relationship between the pulmonary changes of systemic sclerosis and the

TABLE I

CLINICAL DETAILS OF CASES DESCRIBED AND IN THE LITERATURE

\begin{tabular}{|c|c|c|c|c|c|c|c|c|c|}
\hline Case & Sex & $\begin{array}{c}\text { Age } \\
\text { at } \\
\text { Death } \\
(\mathrm{Yr} .)\end{array}$ & $\begin{array}{l}\text { Duration of } \\
\text { Raynaud's } \\
\text { Syndrome } \\
\text { (Years) }\end{array}$ & \begin{tabular}{|c|} 
Duration \\
of \\
Cutaneous \\
Changes
\end{tabular} & $\begin{array}{l}\text { Duration and Nature of } \\
\text { Pulmonary Manifestations }\end{array}$ & $\begin{array}{c}\text { Chest } \\
\text { Radiograph }\end{array}$ & $\begin{array}{l}\text { Type of } \\
\text { Tumour }\end{array}$ & $\begin{array}{l}\text { Histology } \\
\text { of Lungs }\end{array}$ & Metastases \\
\hline 1 & $\mathbf{F}$ & 53 & 18 & $2-3$ years & $\begin{array}{l}3 \text { Years } \\
\text { Dyspnoea, cough, tightness } \\
\text { in chest and recurrent } \\
\text { respiratory infections }\end{array}$ & $\begin{array}{l}\text { Extensive mottling } \\
\text { at lung bases; } \\
\text { right hilar mass }\end{array}$ & $\begin{array}{l}\text { Adeno- } \\
\text { carci- } \\
\text { noma }\end{array}$ & $\begin{array}{l}\text { Marked increase } \\
\text { in fibrous tissue; } \\
\text { cyst formation }\end{array}$ & $\begin{array}{l}\text { Lymph nodes, } \\
\text { pericardium, } \\
\text { liver, stomach, } \\
\text { adrenals, spleen, } \\
\text { pancreas }\end{array}$ \\
\hline 2 & $\mathbf{M}$ & 65 & 1 & 3 months & $\begin{array}{l}\text { 3 Months } \\
\text { Dyspnoea only, pleurisy } \\
\text { with effusion }\end{array}$ & Pleural effusion & $\begin{array}{l}\text { Oat-cell } \\
\text { carci- } \\
\text { noma }\end{array}$ & $\begin{array}{l}\text { Emphysema and } \\
\text { arterial changes } \\
\text { only }\end{array}$ & None found \\
\hline 3 & $\mathbf{F}$ & 65 & 18 & $\begin{array}{l}\text { Present. } \\
\text { Duration } \\
\text { not } \\
\text { recorded }\end{array}$ & $\begin{array}{l}14 \text { Years } \\
\text { Cough with copious muco- } \\
\text { purulent sputum, dysp- } \\
\text { noea, rales at both bases }\end{array}$ & $\begin{array}{l}\text { Bilateral pleural } \\
\text { and parenchymal } \\
\text { densities }\end{array}$ & $\begin{array}{l}\text { Alveolar- } \\
\text { cell } \\
\text { carci- } \\
\text { noma }\end{array}$ & $\begin{array}{l}\text { Diffuse intersti- } \\
\text { tial fibrosis }\end{array}$ & $\begin{array}{l}\text { Liver, kidney, } \\
\text { thyroid }\end{array}$ \\
\hline 4 & $\mathbf{F}$ & 57 & "Always" & $\begin{array}{l}\text { Present. } \\
\text { Duration } \\
\text { not } \\
\text { recorded }\end{array}$ & $\begin{array}{l}10 \text { Years } \\
\text { Exertional and nocturnal } \\
\text { dyspnoea, pleuritic pain, } \\
\text { haemoptysis, rales at both } \\
\text { bases }\end{array}$ & $\begin{array}{l}\text { Infiltrate at both } \\
\text { bases; soft infil- } \\
\text { trate at left apical } \\
\text { region }\end{array}$ & $\begin{array}{l}\text { Alveolar- } \\
\text { cell } \\
\text { carci- } \\
\text { noma }\end{array}$ & $\begin{array}{l}\text { Diffuse inter- } \\
\text { stitial fibrosis }\end{array}$ & None found \\
\hline 5 & $\mathbf{F}$ & 65 & $\begin{array}{l}\text { Not } \\
\text { recorded }\end{array}$ & $\begin{array}{l}\text { Present. } \\
\text { Duration } \\
\text { not }\end{array}$ & $\begin{array}{l}\text { Uncertain } \\
\text { Cough with white sputum, } \\
\text { rales at left lower lobe }\end{array}$ & $\begin{array}{l}\text { Left lower lobe } \\
\text { pneumonia }\end{array}$ & $\begin{array}{l}\text { Alveolar- } \\
\text { cell } \\
\text { carci- }\end{array}$ & $\begin{array}{l}\text { Marked fibrosis } \\
\text { and re-epithe- } \\
\text { lialization }\end{array}$ & $\begin{array}{l}\text { Lymph nodes, } \\
\text { liver }\end{array}$ \\
\hline 6 & $\mathbf{F}$ & 32 & , & $\begin{array}{l}\text { recorded } \\
10 \text { years }\end{array}$ & $\begin{array}{c}\text { Several years } \\
\text { Dyspnoea on exertion only }\end{array}$ & $\begin{array}{l}\text { Diffuse linear } \\
\text { fibrosis; right } \\
\text { hilar mass }\end{array}$ & $\begin{array}{l}\text { noma } \\
\text { Adeno- } \\
\text { carci- } \\
\text { noma }\end{array}$ & $\begin{array}{l}\text { Diffuse fibrosis, } \\
\text { cysts at base of } \\
\text { left lung }\end{array}$ & $\begin{array}{l}\text { Lymph nodes, } \\
\text { liver, adrenals, } \\
\text { bone marrow }\end{array}$ \\
\hline
\end{tabular}

Cases 3-5 are those of Zatuchni, Campbell and Zarafonetis (1953) and Case 6 that of Jonsson and Houser (1956). 
development of carcinoma, but the latter, particularly in view of the fact that their patient was a 32-year-old woman, suggest that there is a connexion between the two conditions. It is not difficult to imagine a direct relationship between a carcinoma of the so-called " alveolar cell " type (Cases 3-5) which arises peripherally and the diffuse pulmonary changes of systemic sclerosis which also affect chiefly the peripheral parts of the lungs. It is more difficult, however, to visualize a connexion between these pulmonary changes and the more common type of bronchial neoplasm which develops in the hilar region and apparently arises in one of the major bronchi (Cases 1 and 6).

A connexion between cancer of the lung and other conditions in which diffuse pulmonary fibrosis occurs has not been conclusively proved. Although there have been suggestions that pneumoconiosis may predispose to lung tumours, the most recent survey by James (1955) indicates that cancer of the lung is not more frequent in coal-miners than in other males and that when carcinoma does develop in coal-miners with pneumoconiosis the tumour is frequently remote from areas of massive pneumoconiosis. Spencer and Raeburn (1954) have drawn attention to the occurrence of nodules of atypical proliferating bronchial epithelium in lungs which are the seat of fibrotic changes associated with either bronchiectasis or chronic heart failure. They are hesitant about suggesting that these may be pre-malignant lesions, and Whitwell (1955), who has described similar lesions, considers them to represent a form of atypical epithelial hyperplasia which is unrelated to bronchal carcinoma. There is, however, good evidence of an association between the haematite pneumoconiosis of iron-ore miners and cancer of the lung (Faulds, 1957). The lung tumours in such cases are usually peripheral in situation and are related to areas of dense pulmonary fibrosis. Faulds (1957) believes that in haematite miners lung cancer arises from damaged epithelial cells at the edge of a peripheral fibrous mass and from there spreads towards the hilum. This is a similar situation to that which we believe may have occurred in the five cases of progressive systemic sclerosis in which fibrosis and cyst formation preceded the onset of the clinical manifestations of cancer of the lung by a number of years. It is worth noting, however, that in these five cases the tumours were either adenocarcinomas or alveolar cell carcinomas, types of tumour which are thought to be unassociated with cigarette smoking or other irritant factors (Kreyberg, 1955).

Case 2 is different from the others. The patient was male and had a relatively short history. Until the terminal stages there was no indication of pulmonary disease. It is probable that the tumour was present and was the cause of the narrowing of the oesophagus in its middle portion which was noted at the time of the barium swallow in September, 1956, when the chest radiograph showed only a small pleural effusion. At necropsy the parts of the lungs unaffected by tumour did not show either the interstitial fibrous or the cystic changes of progressive systemic sclerosis; only arterial lesions were noted. In this case, therefore, the tumour and the cutaneous and vascular manifestations of progressive systemic sclerosis appear to have developed together in a patient with previously normal lungs. Furthermore this is the only case in which the tumour was a bronchial carcinoma of the small cell type which is believed to be associated with cigarette smoking.

Turning to the question of whether there could be an association between progressive systemic sclerosis and malignant disease in general rather than a specific relationship with carcinoma of the lung, the situation is quite different from what is found in dermatomyositis. In cases of the latter disease a wide variety of neoplastic lesions have been found, the most frequent being tumours of the ovary and breast (Brunner and Lobraico, 1951 ; Caldwell, 1955). Carcinoma of the lung is relatively infrequent, although McCombs and MacMahon (1947) and Caldwell (1955) have reported cases of bronchial carcinoma associated with dermatomyositis. Apart from Barlow's case of adrenal adenoma, which was a simple tumour and therefore irrelevant to the present discussion, and the six cases of cancer of the lung which are the subject of this paper, there are only indirect references in the literature to neoplasms associated with scleroderma. Lipman and Tober (1950) described a patient, who, 10 months after resection of a carcinoma of the rectum, suddenly became jaundiced and oedematous and later developed "chronic, classical scleroderma." Curtis and others (1952), when discussing the association of malignant disease and dermatomyositis, stated that they found several instances of neoplasms associated with scleroderma and disseminated lupus erythematosus, but they give no details of these. Zatuchni and others (1953) mentioned three additional cancers in a series of 39 cases of scleroderma; two women with cancer of the 
breast and a man with fibrosarcoma. In the 31 fatal cases of progressive systemic sclerosis reported by Piper and Helwig (1955), there were two patients who had tumours; one was a squamous epithelioma of the thigh which had been removed seven years before the onset of the systemic sclerosis and the other an angiosarcoma of the forehead which appeared 12 years after the development of systemic sclerosis.

There is therefore evidence that there is not the close association between malignant disease and progressive systemic sclerosis that is present in dermatomyositis. The difference is not due to an age or sex factor; the age and sex incidence of dermatomyositis and progressive systemic sclerosis are similar (Talbott and Ferrandis, 1956). It is a common misconception that the latter is a disease of young women. O'Leary and Nomland (1930) found that more than half the patients with generalized scleroderma were over the age of 40 years and a survey of the more recent literature and our personal experience confirm this observation. A considerable proportion of the patients with progressive systemic sclerosis are therefore within the cancer age-group. From the literature the impression is gained that in most of the cases mentioned above the coexistence of neoplasia and systemic sclerosis was fortuitous. This makes it more likely that, in those cases of systemic sclerosis in which respiratory manifestations preceded the onset of malignant disease by a number of years, there is some direct connexion between the pulmonary changes of progressive systemic sclerosis and the development of cancer of the lung.

\section{SUMMARY}

Two cases in which cancer of the lung was associated with progressive systemic sclerosis (generalized scleroderma) are reported. Four other similar cases have been recorded and the findings in the six cases are reviewed. The relationship of the tumours to progressive systemic sclerosis is discussed. There is no good evidence of an intimate association between malignant disease in general and progressive systemic sclerosis such as is found in some cases of dermatomyositis. In only one of the six cases did a bronchial carcinoma and the cutaneous and vascular changes of progressive systemic sclerosis develop together in a patient with previously normal lungs. In the other five pulmonary manifestations of systemic sclerosis preceded the onset of cancer of the lung by a number of years, and in these pathological changes of the primary disease were present in the parts of the lungs unaffected by tumour. There is therefore good grounds for considering that the pulmonary changes of progressive systemic sclerosis may predispose to the development of cancer of the lung.

\section{REFERENCES}

Barlow, G. B. (1939). Arch. Derm. Syph. (Chicago), 39, 1021 Beigelman, P. M., Goldner, F., and Bayles, T. B. (1953). New Engl. J. Med., $249,45$.

Brunner, M. J., and Lobraico, R. V. (1951). Ann. intern. Med., 34 1269.

Caldwell, I. W. (1955). Brit. J. Cancer, 9, 575.

Church, R. E., and Ellis, A. R. P. (1950). Lancet, 1, 392

Cullinan, E. R. (1953). Proc. roy. Soc. Med., 46, 507.

Curtis, A. C., Blaylock, H. C., and Harrell, E. R. (1952). J. Amer. med. Ass., 150, 844.

Dowling. G. B. (1940), Brit. J. Derm., 52, 242.

Faulds, J. S. (1957). J. clin. Path., 10, 187

Faulds, J. S. (1957). J. clin. Path., 10, 187. 28

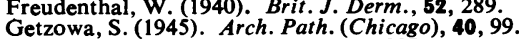

Gotzow, R. H. (1945). Clin. Proc., 4, 337.

Hayman, L. D., and Hunt, R. E. (1952). Dis. Chest, 21, 691.

Israel, M. S., and Harley, B. J. S. (1956). Thorax, 11, 113.

James, W. R. L. (1955). Brit. J. industr. Med., 12, 87.

Jonsson, S. M., and Houser, J. M. (1956). New Engl. J. Med., 255, 413 .

Kreyberg, L. (1955). Brit. J. Cancer, 9, 495.

Lipman, M. P., and Tober, J. N. (1950). Gastroenterology, 16, 188.

Lloyd, W. E., and Tonkin, R. D. (1948). Thorax, 3, 241.

McCombs, R. P., and MacMahon, H. E. (1947). Med. Clin. N. Amer.

31, 1148 .
Mahrer, P. R., Evans, J. A., and Steinberg, I. (1954). Ann. intern. Med., 40,92 .

O'Leary, P. A., and Nomland, R. (1930). Amer. J. med. Sci., 180, 95. Pagel, W., and Treip, C. S. (1955). J. clin. Path., 8, 1.

Piper, W. N., and Helwig, E. B. (1955). A.M.A.Arch. Derm. Syph., 72, 535 .

Shuford, W. H., Seaman, W. B., and Goldman, A. (1953). Arch. intern. Med., 92, 85 .

Spain, D. M., and Thomas, A. G. (1950). Ann. intern. Med., 32, 152. Spencer, H., and Raeburn, C. (1954). J. Path. Bact., 67, 187.

Telncer, H., and Raeburn, C. (1954) M. (1956). Collagen Diseases. Grune and Stratton, New York.

Whitwell, F. (1955). J. Path. Bact., 70, 529.

Zatuchni, J., Campbell, W. N., and Zarafonetis, C. J. D. (1953). Cancer, 6, 1147. 